\section{Foxy logic on gene pursuit}

SIR - Richard M. Lebovitz asks "who else should own the gene but the scientist who first captures it by cloning?" (Nature 382, 17; 1996). An ethical answer is: at least in some part the person from whose tissue the gene was cloned. Lebovitz uses an analogy about ownership of a wild fox. Unlike foxes, human genes are not free-ranging but parts of genomes. Summed over the species, these comprise its gene pool. The scientific utility of this concept should not engender confusion between abstraction and physical reality: at any moment, the genes are parts of the bodies of particular people who in free societies retain rights that are governed by the rules of informed consent.

For example, I have donated blood samples in drives to secure matches for bone-marrow transplants and have signed appropriate consent forms. Had the antigenic correspondence been close, I would willingly have donated the tissue required to save a life. However, if I later found that blood from an unsuccessful screening effort had been used for cloning, sequencing and patenting some of my genes without explicit permision, I would feel cheated and might not respond to further appeals, whatever their stated purposes. It is not surprising to find that members of human populations whose genes have been sampled allegedly for scientific purposes would respond with legal challenges once they discovered that their gene sequences might be patented for financial gain by others (Nature 381, 11-14; 1996).

Geneticists, presumably advised by lawyers more familiar with the ethics of medicine than blood sports, must draft agreements that specify clearly what rights are being conveyed whenever a tissue sample is taken. Samples and sequences unaccompanied by documentation of genuinely informed consent belong in the same category as other goods of dubious ownership: presumed to have been obtained extralegally and barred from commerce. Antiquities markets provide more relevant precedence here than Pierson v. Post.

The hunting parallel fails on other grounds. A fox may be part of nature, but in the United States landowners have a right to say whether anyone may enter onto their lands in its pursuit. Failure to secure permission for hunting on posted lands constitutes trespass. Similarly, oil and gas cannot be sought on private lands without a valid lease; such agreements regularly provide remuneration with initial lease payments and contingent royalties being part of production costs. Why should biotechnology corporations operate differently? In an age of information, scanning genomes for valuable seqences might be more lucrative than drilling lands for oil. The argument that any given gene sequence probably exists in numerous copies could aid a corporate entity in bargaining with several possessors, but it is likely that supply and demand curves will intersect at some monetary value above zero. Each issue of Nature exists in thousands of copies, yet all have value, and the publisher lawfully limits photocopying of the journal's contents.

Oscar Wilde characterized fox-hunting as "the unspeakable in pursuit of the uneatable". Genetic research belongs on a less reproachable plane.

\section{Robert B. Eckhardt}

Pennsylvania State University,

University Park, Pennsylvania 16802, USA

e-mail: eyl@psuvm.psu.edu

\section{Low impact}

SIR - In the past decade, the rather peculiar criteria for academic promotion in Italy have attracted international attention. Instances of controversial appointments to tenured positions at the full or associate professor level have been denounced in journals such as Nature and the Lancet. Losers have quite frequently seemed to have far better scientific credentials than winners, particularly on the basis of citation analysis.

For those not familiar with Italian academic life, it is difficult to know whether such episodes represent the unavoidable drawbacks of an obsolete system of academic promotion (whereby all vacancies are submitted to the Ministry of University in Rome and all appointments are carried out by national committees every 4 to 5 years) or are indicative of more widespread corruption.

An analysis of the performance of Italian science, based on the Institute for Scientific Information (ISI)'s National Science Indicators on Diskette (NSIOD), suggests the latter interpretation. The NSIOD is a database of summary publication and citation statistics reflecting research performance in the sciences by 90 countries between 1981 and 1994. The database contains counts of publications and citations taken from the peer-reviewed journals indexed by ISI.

These data cover 22 fields, and in every case the Italian citation impact is lower than the world citation impact, even in fields of traditional strength and excellence such as physics and chemistry. The mean percentage of fall in impact compared to the world impact is 32 (s.d.=16). If the impact for 1990-94 is compared to that for 1981-85, Italy is losing ground compared to the rest of the world in a number of areas, including 3 of the 5 top fields of Italian science, materials science $(-0.15)$, physics $(-0.26)$ and mathematics $(-0.10)$. More direct compar- isons can be made within the European Union. Despite a sizeable number of papers published during the period 1981-94 $(210,766)$, the Italian citation impact for all fields (6.34) is higher only than those in Ireland, Portugal, Spain and Greece.

There are several explanations for the current failure of Italian science, including the lack of investment in research and technology by the (many) Italian governments throughout the years. But decades of arbitrary decisions on academic promotion, research appointments (even inclusion in $\mathrm{PhD}$ programmes) and funding assignments are likely to exact a heavy toll on the state of science in Italy. The failure of teaching not more than a third of the students who enrol eventually graduate - is another manifestation of the struggle for power in Italian universities, which disregards scientific merit and genuine academic interest.

Giovanni A. Fava

Department of Psychology, University of Bologna,

Viale Berti Pichat 5,

1-40127 Bologna, Italy

\section{Innovations catalogue}

SIR - Terence Kealey's latest book has received much comment, including that in Nature (383, 123-124; 1996), but it begs some questions. If technology is "largely derived from the industrial development of pre-existing technology", one wonders where did it all begin? With the wheel? Surely Super CRAYs and PCR analysis (for instance) owe their origins at least as much to inquiring minds unfettered by commercial constraints as to the incremental refinement of pre-existing technology back to the year dot?

Second, if Kealey's hypothesis is right, then why is UK manufacturing increasingly keen to collaborate with universities (now up to $31 \%$ of companies - Research Fortnight 12 June, page 12) and turning away from its own in-house research? Furthermore, the Confederation of British Industry (CBI) is reported as saying that "[s]uch cooperation helps to spread risk and enhance the intellectual and skills pools available to companies".

Following on from this, the other question Kealey's readers might ask is who is he speaking for? $\mathrm{He}$ is speaking for himself certainly, but not for the many scientists who would like to see the UK science base enhanced (as demonstrated by the evidence submitted before the 1993 White Paper on science and technology), nor it would seem, given the CBI view, for industry.

\section{Jonathan Cowie}

5 Charlieville Road,

North Heath, Kent DA8 1HJ, UK 